\title{
Changes in the Matrilineal System within Minangkabau Children's Carito
}

\author{
Satya Gayatri'; Ida Rochani Adi²; Wening Udasmoro \\ ${ }^{1}$ Faculty of Cultural Sciences, Universitas Andalas, Indonesia; \\ ${ }^{2}$ Department of Language and Literature, Universitas Gadjah Mada, Indonesia \\ Email: satyagayatri@hum.unand.ac.id
}

\begin{abstract}
This article explores the transformation of the matrilineal system within Minangkabau children's carito. In general, children's carito are considered bedtime stories that convey positive values; as such, research into them has focused on values. Children's carito have been collected through interviews with storytellers who retain the carito within their memories. The memories of these storytellers have changed together with changes in the storytellers themselves and in their environments. To explore the changes in the matrilineal system within the carito, one story has been analyzed over three generations (from grandparents, parents, to children). Changes in the matrilineal system are evidenced through the carito characters' emergence and disappearance, their actions, and their interactions with their mothers, who - as in the matrilineal system - are central within the carito. Changes, differences, and behaviors within the carito indicate the dynamic transformation of communal families to conjugal families and ultimately nuclear families.
\end{abstract}

Keywords: Minangkabau children's carito; social change; matrilineal system; storytellers; characters

\section{INTRODUCTION}

In the Minangkabau language, the word caritohas the same denotative meaning as the word cerita in Indonesian or story in English. However, in Minangkabau culture, a caritois not always fiction; a caritomay also be news or information that may or may not have an element of truth. 'Story', in this case, thus refers to narrative that is conveyed orally.In Minangkabau culture, there are two types of carito: stories for adults and stories for children. Stories for adults are known as kaba, take the form of lyrical prose, and tend to function as entertainment (Navis, 1984, p. 243; Junus, 1984, p. 17).Presently, many kaba have been written and even translated into Indonesian (Yusuf, 1994; Djamaris, 2001).Stories for children, meanwhile, are more properly known as carito, and thus in this article are referred to as such. Minangkabau children's carito tend to be oral (except for Carito Malin Kundang) and widely known, with many retellings and transformations into new stories or works (Navis,
1999; Junus, 2011; Ronidin, 2011). Some Minangkabau children's carito have been written in Jawi, with examples being held at the Leiden University Libraries; however, these have not been used by the Minangkabau for over a century (Djamaris, 2001, p. 12).

Minangkabau children's carito, as with other forms of traditional literature, are intended to convey positive values and messages to their audience(Koster, 1995, p. 51; Sikana, 2007, p. 15; Sukatman, 2009, p. 8; Tulius, 2012, p. 23). Interestingly, many Minangkabau children's carito tell of a child who does not respect or ethically behave towards his/her mother-despite Minangkabau being known for its matrilineal culture that greatly honors women. Such a phenomenon is found in carito through all parts of the Minangkabau realm, from the luhak (highlands) to the rantau (diaspora) and pesisir (coast).

The traditional Minangkabau kinship system was matrilineal and communal, with the division of 
inheritances, fields, and housing being prioritized for women and supervised by the mamak (male sibling of the mother).The settlement patterns under this matrilineal system were bilocal, with power in a single zuriat (extended family) being held by the mamak (BendaBeckmann, 1981; Navis, 1984, p. 126; Yunus, 2015, p. 51; Kato, 2005; Jamaris, 2004, p. 15).The Minangkabau are devout Muslims, even though Islam is firmly patrilineal (Kahn, 1980, p. 6; Benda-Beckmann, 1981 and 2012; Azra, 2003,p. 45; Nizal, 2008, p. 68), and are prominently characterized by the diaspora culture known as rantau, in which persons travel away from their home villages or homelands (Kato, 2005; Naim, 1985; Iman, 2013). Over time, these two systems brought significant changes to the matrilineal system, influenced by the dynamics of the Minangkabau society (Martono, 2012, pp. 17-18). It can be assumed that changes in the matrilineal system can be seen in Minangkabau children's carito.

Presently, social interest in Minangkabau children's carito is limited, both among the older and younger generations; as such, the researcher had difficulty identifying informants. Members of the older generation refused to be interviewed, citing an inability to remember the carito, while the younger generation (the children/ grandchildren) refused because they had never been told these carito. However, using an intensive approach and after a considerable amount of time, finally informants who were accurate, credible, and capable of retelling the carito well.The selection of informants was important for this research, as oral culture contains the information and collective social values of the society in which it exists (Teeuw, 1994, p. 22). As such, informants were needed who were indigenous Minangkabau, who lived (and long resided) in areas where carito were told, and were traditional leaders, religious leaders, social leaders, or bundo kanduang (the oldest woman in a rumah gadang).

Intense research into oral Minangkabau children's carito has yet to be found, indicating the increased marginalization of these stories. Research has been conducted into a literary work inspired by a Minangkabau children's carito, a short story by A.A. Navis (2005) titled "Malin Kundang, Ibunya Durhaka"("Malin Kundang, His Mother was Faithless"). Carito Malin Kundang (The Story of Malin Kundang), as a traditional carito, can be examined within its own time, because carito are not monolithic (Junus, 2011), and the carito does not always tell of a faithless son. According to Ronidin (2011), Navis' story is a parody of Carito Malin Kundang.

Research into children's literature has generally examined works of children's literature that were written based on oral tradition. Children's carito and children's literature have several similarities, such as easily understood and transparent stories/plots and a lack of adult or sexual elements (Noderman, 2008, p. 143; Sarumpaet, 2010). The main difference is their dissemination; children's carito are spread orally, while general children's literature is written. Research into traditional literature outside of the Minangkabau context has been conducted, for example, by Musfiroh (2008), who has examined the techniques for choosing, preparing, and presenting fairy tales to young children. Fairy tales can inspire children's imaginations and teach them positive values. Supartinah (2013), in her examination of the classical children's literatures of the Indonesian archipelago, has analyzed the values of these literary works, their role in shaping children's characters and identities, and the extent to which they inspire creativity in schoolchildren. Riyadi et al. (1995) examined Javaneselanguage children's stories using a structural approach. These works of children's literature have been transcribed and published in Javanese-language media.

Unlike previous research, this article attempts to analyze Minangkabau children's literature by comparing the versions of carito told by different generations, with a focus on shifts in the matrilineal system. Changes are made to carito by their storytellers in accordance with contemporary trends when the carito is told. In oral literature, memory and verbal abilities are valuable assets (Ong, 2013, pp. 85-87). The quality of a storyteller is determined not by the ability to formulate a plot, but by their narrative ability (ibid, 2013, pp. 215-218). The memories of storytellers are dynamic and are influenced by their social conditions; as such, the memories of storytellers of different generations differ (Tumblety, 2013; Ahmadi, 2009; Walgito, 1980). Research into memory has developed as interdisciplinary study, intersecting with social studies, the humanities, the natural sciences, media studies, performance arts, etc. Memories contain within them incidents and events that may be forgotten, and given the mental limitations of individual people certain activities are necessary to ensure these things are remembered (Jones, 2007; Erll, 2011). In oral literature, memory is important, and one characteristic of oral literature is variability in performance and form, with stories being similar but not the same. Such form provides a basis for most of the texts that are analyzed (Finnegan, 1992, p. 150). Changes and differences in oral literature are things that are occur naturally, and follow developments in society and its thought (in Esten, 1992, pp. 16-17; Junus, 1986). Presently, many works of oral literature have transformed into modern forms using technology, presenting what is known as secondary orality 
(Ong, 2013, p. 7 and 31). However, a negative effect of this secondary orality is the disappearance of oral tradition and the erosion (or even erasure) of social contact. As a result of such changes in media, children (audience) do not communicate sufficiently with storytellers and their environment (Sugihastuti, 2013). As such, research into oral literature is urgent, to ensure that the memories of older and younger storytellers are preserved and parents interact with their children.

The theoretical frameworks of this research are oral literature, memory, and social change. As a form of oral literature, children's carito have the following characteristics: 1) do not use written media, but are conveyed orally, 2) are developed in simple, undeveloped, illiterate, rural societies, 3) express certain cultures, 4) have no specific author, and thus are found in many versions, 5) have a lengthy history, 6) do not emphasize facts, but entertainment and education (Sikana, 2007, p.16; Endraswara, 2009; Taum, 2011; Mursini, 2011; Simatupang, 2011).

This research provides a qualitative study using the snowball technique for sampling (Miles, 1992, p. 47). Data was collected from a 'chain' of subjects over time, with respondents leading to further respondents. A total of ten carito are used as samples, collected from the three traditional Minangkabau territories (luhak, rantau, and pesisir). The carito collected from the luhak were Carito Sapan Mandidiah, Carito Aia Mangalogak, Carito Boncah Tangkuluak, and Carito si Buncik. Four carito were collected from the rantau territories, namely Carito Bancah Biunguik, Carito Batu Bangkai, Carito Bukik Balacan, Carito Batu Manangih, and Carito Tobek si Ombie. From the pesisir, meanwhile, one carito was collected: Carito Awang Tingkuluak. These carito were conveyed orally and recorded using a digital camera and handycam, and were also noted manually. The recordings were then transcribed and translated into Indonesian. Analysis of shifts in the matrilineal system could only be conducted if versions of each carito were collected from members of three generations (grandparents, parents, children), with an estimated chronological gap of twenty years or more. The informants selected from the grandparents and parents' generations were niniak mamak, alim ulama, cadiak pandai, bundo kanduang, or other social figures, while informants selected from the children's generation were students in elementary school and junior high school.

This analysis was supported by interviews, as written sources were either lacking or non-existant. Interviews were conducted with older informants or other persons who experiencedbacaritotradition, story telling tradition in the past, as appropriate for historical studies (Koentjaraningrat, 1990, p. 252). Before communities became literate, oral tradition was used to document the present and to present the past in the present (Vansina, 1985).

\section{FINDINGS AND DISCUSSION Memory and Change in Minangkabau Children's Carito}

In oral literature, the concept of "memory" is important because texts are conveyed orally based on memory. The act of remembering is used by storytellers to obtain materials from other storytellers, and to pass these materials to their successors. All forms of storytelling activities are held within their memories (Teeuw, 1980; Koster, 1995, pp. 39-40). In oral tradition, stories are told verbally, from the easiest to the most complex forms, and used to present teachings, morals, and life problems (Finnegan, 1992, p. 150; Taslim, 2010, p. 19). However, humans may forget certain things because they have a limited ability to remember things, and owing to such physical conditions as exhaustion, illness, lack of sleep, or emotion (Ahmadi, 2009, p. 73). One benefit of memory is the ability to recognize and remember (but you just said they might forget, maybe change the word into "select") things (Walgito, 1980, p. 162; Ahmadi, 2009, p. 73). According to F. C. Barlett, when telling a story there are many changes, and these changes to stories (as familiar narratives) lead to new versions. As such, elements of an oral story may disappear or fall out of favor, indicating a transition from earlier versions (in Finnegan, 1977, p. 143).

Owing to individuals' limited memories, the telling of carito is strongly influenced by the storyteller's age. This reality is seen in the field, where many informantsparticularly from the older generations - had difficulty recollecting the desired information. The researcher thus had to use various approaches to collect the information sought from their memories. In one case, an informant was able to remember a carito and begin telling it. However, in the middle of telling the story the informant was no longer able to remember the story. At the time, the informant was about 60 years old. The informant's inability to remember the remainder of the story is evidenced in the informant's responses during the interview, as follows:

$$
\begin{array}{cl}
\hline \text { Informant }: \begin{array}{l}
\text { Sahinggo itu dek den takona } \\
\text { caritonyonyo. Sudah itu ntah baaa. }
\end{array} \\
\text { Researcher : } \begin{array}{l}
\text { Akhirnyo baa lai? Carito nan } \\
\text { potang?(...) }
\end{array}
\end{array}
$$




\begin{abstract}
Informant : Iyo nyo kadang-kadang dapek pangkanyo hilang tongahnyo. Jadi dek urang nan pandai,bisa panjang, tapi dek awak saketek-keteknyo.

Researcher : Ado carito dari urang gaek yang lain ndak? Salain carita itu?

Informant : Salain carita itu, ndak tau lai.
\end{abstract}

\section{Translation}

Informant : That's as much as I remember of the carito. After that, well I don't know.

Researcher : And what else? The earlier carito? (...)

Informant : Yeah, sometimes I get bits and pieces, with parts missing. So a smart person could tell it at length, but I know just a bit.

Researcher : Are there any other carito from your parents? Other than that story?

Informant : Other than that carito, I don't know.

Traditions are ever changing in response to changing perspectives, knowledges, and technologies, although they cannot always satisfy all stakeholders. However, these changes must not be too extreme, as otherwise they may be rejected by members of society; changes, at the local, regional, and global level, can only be accepted to a certain extent (Rubin, 1995, p. 10; Salim, 2014). Change is an unnegotiable fact of life, for humans as social beings must interact with the world outside them, either directly or indirectly; as such, change can happen at any time. Change is not a single physical entity, but rather a series of interlinked processes, traditions, material artifacts, and ideas (Sztompka, 2014, p. 3 and 73; Soekanto, 2015, pp. 17-18). The more developed a society, the more obvious the change. A person's memory is also influenced by the social changes experienced by the society around him or her. One female informant, who had been a teacher in her youth, was unable to retell the carito she had heard from her grandmother (whom she called Mayai) in her youth. It had been a tradition for the informant's grandmother to tell a carito in the rumah gadang to the informant and her siblings and cousins. However, when interviewed, she was unable to retell the carito she had heard in her youth because she had already forgotten them. The informant had also not continued the tradition of bacarito to her grandchildren because the situation had changed. Her grandchildren were calm and even lulled to sleep while watching television, be it either their television program "Upin dan Ipin"(Upin and Ipin) or other cartoons. Before, children would go to sleep while listening to carito or being carried by their parents and listening to their songs, something known among the Minangkabau as manjunjai (Yunus, 2015, p. 252). This is indicated in the following quotation from her interview:

\section{Researcher : Ado carito nan takona dek ni Yen? \\ Informant : Ndak, orang kini ndak bacarito do. Kalau dulu mandiang Mayai iyo bacarito. Baaitu nan kau yo. Ntu awak lah takolok sajo dalam itu lai. Kini anak lah nonton tv. Lahtakolok sajo di muko tv lai. Nan ba tipe.Kalau dulu baendong-endongan.Kiniendong- endongan ndak ado lai. \\ Researcher : Dulu urang gaek iyo bacarito iah Ni? \\ Informant : Iyo. Mandiang Mayai dulu. Caritonyo itu baa awak ndak elok laku. Jan ditiru. Modelitu Kalau nan buruak nan dicaritoannyo ado akibatnyo (...)}

\section{Translation}

Researcher : Are there any caritothat you remember, Uni Yen?

Informant : No. People today, they no longer bacarito.Before, my late Mayai, yeah bacarito. Like that. Now, we just go to sleep at that time. Now children are watching television. They just go to sleep in front of the television. Before, they were carried in slings. Now there aren't any more slings.

Researcher : Before, your parents bacaritothen Ni?

Informant : Yes. My late Mayailiked to bacarito. The caritowas all about how we could behave well. Not mimic certain things. The bad things, in the carito, they all had consequences (...)

From the colonial period and into the present day, education has influenced the everyday lives of Minangkabau society. The Minangkabau have shown a strong interest in and desire for education, even in the most rural areas, Anybody who is well-educated would be "respected"by society (Azra, 2003, p. 121; Graves, 2007; Dobbin, 2008; Effendi, 2016, p. 17). The influence of education was also used to convey memories to children, 
which in memory theory is known as "cultural memory", a process through which the experiences of individuals are shared with other individuals and subsequent generations (Erll, 2011, p. 28). The tradition of telling carito changed. Before, it had been done in the rumah gadang (for female children) or in the surau (for male children) (Hadler, 2010, p. 193), but now the tradition is also done at schools. Child informants for the Carito Batu Bangkai, Carito Bancah Biunguik, Carito Bakik Balacan, Carito Tobek si Ombie, and Carito Si Buncik stated that they had heard and memorized these carito while in school. Their teachers had taught them these stories while they were in kindergarten and elementary school. Schools, thus, have become effective institutions for conveying carito, replacing the rumah gadang and surau that had been used by the grandparents' and parents' generations. The rumah gadang and surau are no longer inhabited, and many have become dilapidated as a result of disuse (Stark, 2013).

Changes in language use have also been found in child informants' telling of carito. These changes have occurred because the children's generation, even in rural areas, has become used to speaking Indonesian at home and in their everyday lives. According to one study into the use of the Indonesian and Minangkabau languages in Padang, the use of Indonesian has increased, particularly among the younger generation. These children perceive the use of Indonesian as politer than the use of Minangkabau (Marnita, 2015). Similarly, in rural areas, a questionnaire distributed among seventeen third-year elementary school students found that four of them communicated with their parents in the Minangkabau language, twelve used both Indonesian and Minangkabau, and one did not respond. As such, the Indonesian language has become commonly used in rural villages, and it is thus possible that Minangkabau children's carito are no longer being told in Minangkabau but in Indonesian.

\section{Changes in the Matrilineal System in Minangkabau Children's Carito}

Carito, as cultural products, change over time together with their society; a tradition that does not change will be abandoned by its society (Rosidi, 1995, pp. 125-126). Several observers have noted that the matrilineal system in Minangkabau society has begun changing, but has yet to be erased (Azra, 2003; Erwin, 2006; Benda-Beckmann, 2012). If the matrilineal system were to disappear, so would Minangkabau. People may change their lifestyles, citizenships, and even their religions; however, they may never change their origins or their roots (Anwar, 1995, p. 16).
There is little written testimony of Minangkabau culture before the arrival of Dutch colonialism. However, there is a traditional oral history, or tambo, that is frequently told in traditional ceremonies (Kato, 2005, p. 18; Djamaris, 1991). It is possible that the matrilineal system was first implemented when men began going on the rantau (diaspora), expanding their agricultural lives. As women were frequently left by their husbands, they were the ones who became closest to their children, over time creating a matrilineal system (Naim,1984, p. 59). In the matrilineal Minangkabau tradition, the mamak (older brother of the mother) is the leader, providing guidance, support, and supervision, as well as maintaining the family's wealth and heirlooms. As such, the character of a Minangkabau child was shaped not only by his/her parents, but also by his/her mamak (Navis, 1984, p. 130; Erwin, 2006; Chatra, 2015).

The matrilineal system has several characteristics: a) lineage following the matrilineal line, b) matrilocal marriage, c) kinship rooted in a shared fate and honor, d) essential power being held by the mother and technical power being held by the mamak, d) bilocal residences, f) the paruik as the smallest family unit, g) passage of inheritance from the mamak to his nieces. The mamak, thus, served as the male authority, but lived with his mother; although he was part of the lives of his wife and children, he remained a part of his mother's family (Navis, 1984; Jamna, 2004, pp. 35-36; Hadler, 2010, p. 9; BendaBeckmann, 2012).In such a matrilineal society, daughters were very important, as they were the ones who would continue the family line. As such, they were honored and protected (both physically and mentally). The importance of women in Minangkabau culture is also evidenced in the carito. In essence, all of the carito used as samples convey the importance of honoring and respecting one's mother. If this is not done, the consequences may be fatal for the child, as shown in these carito by children turning into stone or being buried in mud. All of these carito have a mother as a main and central character. The dominance of female characters is also shown in the presence of daughters in four of the carito, namely Carito Sapan Mandidiah, Carito Bancah Biunguik, Carito Batu Bangkai, and Carito Awang Tingkuluak; meanwhile, male children are only found in Carito Si Buncik, Carito Batu Balacan, and Carito Tobek si Ombie. Carito Batu Bangkai has the most male characters - the child, husband, mamak, and gambler - while the other carito have no male characters. The dominance of female characters can be seen in the following table.

The lives of the Minangkabau changed with the entry of Islam into the region and institutionalization of 
Table 1: Dominance of Female Characters in Carito

\begin{tabular}{|c|l|l|l|l|l|l|}
\hline Carito & \multicolumn{2}{|c|}{ Female } & \multicolumn{3}{c|}{ Male } \\
\hline Sapan Mandidiah & mother & child & & & \\
Batu Biunguik & mother & child & & & \\
Batu Bangkai & mother & child & & gusband & mamak & \\
Awang Tingkuluak & mother & child & & & \\
Si Buncik & mother & & child & & \\
Bukik Balacan & mother & & child & & \\
Tobek si Ombie & mother & & child & & & \\
\hline
\end{tabular}

the surau, which initially served as a place for teaching Islam but has been left gradually (Azra, 2003, p. 7; Nizal, 2008, p. 75). Furthermore, social change occurred in Minangkabau society as a result of numerous factors, including education, migration, finance, government, and technology (Naim, 1984; Manan, 1995; Erwin, 2006; Arifin, 2009; Hadler, 2010). As a result, the matrilineal family system of the Minangkabau experienced several changes:

a) the family structure became oriented towards the nuclear family; b) the reduction in the number of traditional houses, which were centers of education in matrilineal families; c) the reduction of the surau's function as a center for religious and physical education; d) the reduced attribution of traditional values to the practice of rantau, replaced by economic factors and a desire for self-development; e) the integration of Islam, the only religion of the Minangkabau, into tradition; family members' emphasis of matrilineal lines in their interactions shifting to schools, workplaces, entertainment, and other venues (Jamna, 2004, p. $5)$.

In accordance with these changes, there were shifts in the family bonds and responsibilities, in which responsibility for children became "dominated" by their parents. The mamak, as a result, no longer had full responsibility for their nieces and nephews, as these nieces and nephews had their fathers (Azra, 2003, p. 17; Yoeti, 2017, p. 119). Similarly, grandparents and mothers' sisters began paying less attention to children, as they were no longer living and sleeping in the same rumah gadang. Family members who had lived in a rumah gadang together lived on their own, particularly those who were well-to-do, given the material cost of maintaining a rumah gadang (Salim and Zulkifli, 2004, p. 47). In Islamic teachings, the parents are responsible for the education and future of the family, and the father is the head of the family. Because of this teaching, Minangkabau men became more responsible for their wives and children than their communal families and their nieces and nephews (Nizal, 2008, p. 72; Azra, 2003, p. 47).

In several carito, father characters do not play a role in the plot, but it is stated that these characters have died or that the mother character is a widow. This indicates a belief that the father is responsible for the lives and prosperity of their families, as the family fell into poverty after the father character's death. These father characters, thus, are very important, as in death these father characters cannot ensure the prosperity of their families, as seen in the parents' version of Carito Bancah Biunguik, parents' and children's versionof Carito Tobek si Ombie, and the parents' and children's version of Carito Awang Tingkuluak. In this research, parent informants were assumed to have been born c. 1975 and aged between 30 and 45 , while child informants were born after the 2000s.In both of these periods, the nuclear family model was dominant in Minangkabau society, and the communal family was less involved in everyday life. The communal family would only become involved in family life during traditional ceremonies and during times of joy and grief (Anwar, 1995). In these carito, the father characterswere thus important, fully responsible for their nuclear family, as found in Minangkabau families today. The following table shows other parts of the carito, which show the importance of the father character. See table 2.

In the grandparents' versions of Carito Bancah Biunguik, Carito Tobek si Ombie, and Carito Awang Takuluak, no father character is present or referenced. These informants were born and raised before or around the $1950 \mathrm{~s}$, at a time when fathers had yet to take a dominant role (as in the time of the parents and children). In the grandparents' childhoods, the sense of communal 
Table 2 a: Parts of Carito regarding Father Characters

\begin{tabular}{|c|c|c|}
\hline $\begin{array}{c}\text { Carito Bancah Biunguik } \\
\text { (Parents' Version) }\end{array}$ & $\begin{array}{c}\text { Carito Tobeh si Ombie } \\
\text { (Parents' Version) }\end{array}$ & $\begin{array}{c}\text { Carito Awang Tingkuluak } \\
\text { (Parents' Version) }\end{array}$ \\
\hline $\begin{array}{l}\text { Ado induak baduo baranak } \\
\text { yang ndak ado puno ayah. Jadi } \\
\text { anakno ko maleh-malehlah karajo, } \\
\text { dimanjoanlah inyo dek amaknyo ko. } \\
\text { Inyo yo lai bantuaknyo rancak. Jadi } \\
\text { apopun karajo urang tuojo ngarajoan } \\
\text { sado alahnyo. Atulah lamo, dek indak } \\
\text { baayah ado, tu kehidupan makin lamo } \\
\text { makin payah. }\end{array}$ & $\begin{array}{l}\text { Nyo kan carito e si Ombie ko durako } \\
\text { ka ibu e. Nyo dari ketek jo ibue ndak } \\
\text { ado jo ayahe, keceknyo do. Jadi ibue } \\
\text { yang manggadang-annyo tingga di } \\
\text { ateh bukik Koto Aua.Jadi tulah dek } \\
\text { payah di kampuang pai marantau ka } \\
\text { Medan }\end{array}$ & $\begin{array}{l}\text { Ado anak gadih, inyo tu dek anak } \\
\text { surang tantu sayang bana urang } \\
\text { gaeknyo, urang tuo laki-lakinyo alah } \\
\text { maningga. Jadi dek anak iko anak } \\
\text { surang sayang bana urang gaeknyo } \\
\text { iko khan?, jadi anakko agak kurang } \\
\text { tau diri jadinyo }\end{array}$ \\
\hline $\begin{array}{l}\text { (There was a mother of a child who } \\
\text { had no father. Soher child was lazy } \\
\text { all the time, spoiled by her mother. } \\
\text { She was quite pretty. So whatever } \\
\text { work there was, the mother did } \\
\text { everything. Over time, because there } \\
\text { was no father, of course the two of } \\
\text { their lives became harder.) }\end{array}$ & $\begin{array}{l}\text { (This is the story of Ombie, who } \\
\text { was unfaithful to his mother. From } \\
\text { youth, he had been with his mother, } \\
\text { not with his father, he said. So his } \\
\text { mother had raised him, living there } \\
\text { atop Mount Koto Aua.Because things } \\
\text { were so hard in the village, he went } \\
\text { on the rantau to Medan) }\end{array}$ & $\begin{array}{l}\text { (There was a young girl, and as a } \\
\text { daughter of course she was loved by } \\
\text { her parent. Her father had died. So } \\
\text { because she was the only child, of } \\
\text { course she was loved by her parent, } \\
\text { right? So the girl grew up not really } \\
\text { knowing her place.) }\end{array}$ \\
\hline
\end{tabular}

Table 2 b. Father Character in Carito

\begin{tabular}{|c|c|}
\hline $\begin{array}{l}\text { CaritoTabek si Ombie } \\
\text { (Children's Version) }\end{array}$ & $\begin{array}{l}\text { CaritoAwang Takuluak } \\
\text { (Children's Version) }\end{array}$ \\
\hline $\begin{array}{l}\text { Lai dulu sabuah kampuang di ateah dakek Tanah Gani. Di sinan } \\
\text { tingga omak jo anak e. Ayahnyo lah maningga. Dimanjoannyo } \\
\text { anaknyo sompai godang dek omak e du. } \\
\text { Tu marantau anak e siap tu. Tu mintak pitih e ka omak nyo, ndak } \\
\text { amuah amak e magiah do. } \\
\text { (There was once a village up top, near Tanah Gani. There lived a } \\
\text { mother with her son. His father had died. The child was spoiled } \\
\text { rotten by his mother. After that, the child was ready to go on } \\
\text { the rantau.After that, he asked his mother for money, but she } \\
\text { wouldn't give it to them.). }\end{array}$ & $\begin{array}{l}\text { Ado urang jando. Nyo baranak surang. Anaknyo ko } \\
\text { ancak. Satiok hari anaknyo ko ndak nio manolongan } \\
\text { induaknyo ko do. Satiok disuruh induak nyo ko nda } \\
\text { nio nyo do. Karajo anak ko bagaya sajo. } \\
\text { (There was a widow.She had one child. That child } \\
\text { was so pretty. Every day, child wouldn't help her } \\
\text { mother. Everything her mother asked her to do, she } \\
\text { refused. Her only work was acting out.) }\end{array}$ \\
\hline
\end{tabular}

family remained strong, and responsibility for the family was not borne entirely by the father.

In the parents' version of Carito Batu Bangkai, there is a mamak character that speaks to the mother character. However, in the children's version of Carito Batu Bangkai, the mamak character does not appear; instead, he is replaced by a husband character. In the children's version, there are thus two significant changes. Where in the parents' version the mother became pregnant outside of marriage, in the children's version the mother became pregnant with her husband. In this story, this woman's mother forbade the pregnant woman from taking rice to her husband in the field. The pregnant woman did not listen to her mother's instructions, and thus showed more concern for her husband. Her unwillingness to listen to her mother led to them fighting. In Table 3 below, it is shown how these versions of Carito Batu Bangkai presented the characters.

The description of events in the children's version of Carito Batu Bangkai showsthe strong bonds within the nuclear family (between wife and husband). This is shown from behavior of the woman, who refused to listen 
Table 3: Caritoshowing the Mamak and Father Characters

\begin{tabular}{|l|l|}
\hline \multicolumn{1}{|c|}{$\begin{array}{c}\text { CaritoBatu Bangkai } \\
\text { (Parents' Version) }\end{array}$} & $\begin{array}{l}\text { CaritoBatu Bangkai } \\
\text { (Children's Version) }\end{array}$ \\
\hline $\begin{array}{l}\text { Jadi kato mamak now jo induak nok", "Kalau kau soman iko, } \\
\text { waden diusia, kato amak now. Jadi, pado induak now to tausia, } \\
\text { jadi anak ko diusia now. Disuruah now pai anak now ko. }\end{array}$ & $\begin{array}{l}\text { Inyo padusi sadang hamil. Laki now mambajak di } \\
\text { saw di Batu Bangkai. } \\
\text { Now pai mantaan nasi ka laki now ka sawah tu. } \\
\text { Jadi lah disiap ie now nasi tuak laki now cako. } \\
\text { Dilarang now dek amak now, "Jan pai lai laiek." } \\
\text { Tapi nyo taruih jo pai tu. }\end{array}$ \\
$\begin{array}{l}\text { (So the mamak told the mother, "If you do this, I'll be chased } \\
\text { out, she said. So, rather than her being chased out of the village, } \\
\text { the child was sent away. They told the child to leave.) }\end{array}$ & $\begin{array}{l}\text { (She was a woman, pregnant. Her man was plowing } \\
\text { the rice fields in Batu Bangkai. } \\
\text { She went to take the rice to her husband. She } \\
\text { went to the fields. So she prepared the rice for her } \\
\text { husband. Shewas forbidden from doing this. "Don't } \\
\text { go to seeyour husband". But she still went). }\end{array}$ \\
\hline
\end{tabular}

to mother and decided to take the rice to her husband. The strength of these nuclear family bonds is made clearer in the description of the husband plowing the fields. Traditionally, in Minangkabau society, during the day a husband would work the fields or at their parents' home, rather than stay at home or at the home of the wife's family (as seen in Carito Batu Bangkai). The husband did not work the fields of the wife's family because this was done by the mamak. The mamak was responsible for working, monitoring, and protecting the communal family’s fields (Tanner, 1982; Navis, 1984, p. 153; Kato, 2005; Hadler, 2010, p. 9).

From the activities done by the characters, it is seen the change of matrinineal family type in Minangkabau from communal to extended family, i.e. nuclear family added with grand mother, mamak (uncle) and, cousins, and etek (aunt) (Sudiharto, 2007), to batih family by the presence of a husband in children's version story. The following is the sequence of change (Gayatri, 2017).

Grandparents' Version | Parents' Version | Children's Version

\section{communal family $>$ conjugal family $>$ nuclear family}

In traditional Minangkabau families, the behaviors and attitudes of nieces and nephews were shaped by their parents and their mamak, as taught in the Minangkabau idiom nan sakik kato, nan malu tampak, malu indak buliah diagiah, suku indak buliak dianjak, malu surang malu basamo (the pain is said, the shame is shown, shame must not be brought, the group must not be changed, the shame of one is the shame of many) (Zainuddin, 2013 , p. 19).If a member of society behaves in a way that violates traditional norms, that person will receive social or material sanctions. As in the carito above, the mother and mamak would be driven out of the village because the daughter/niece became pregnant outside of marriage. This was a social sanction of the communal family. A daughter becoming pregnant outside marriage would bring shame to the whole family, especially the mamak, because the mamak would be seen as incapable of teaching his niece. As such, if an individual violated social norms, the mamak would be blamed because the individual would have been taught by their mamak and parents (Yunus, 2015, p. 27).

The shift in emotional ties between mothers and children is seen in Carito Bancah Buinguik. In the grandparents' version, the mother character allows her daughter to be buried in mud, screaming and cursing, and is unwilling to help the daughter as she is covered. The attitude of the mother differs in the versions of the parents and children. In these versions, the mother exhibits a dependence on and responsibility for the daughter, even though her daughter treats her like a servant. The behavior and attitude of the child does not change her mother's love and concern for her. The mother attempts to help her daughter and protect her from being covered in mud, even though the daughter is ultimately swallowed by the mud.

By examining the incidents in the caritoand comparing the attitudes and behaviors of the characters, a shift in the 'emotional' bonds between the parent (mother) and child can be seen. Before the 1980s, when Minangkabau society was not heavily influenced by globalization and the traditional Minangkabau family remained common, children did not only have 'emotional' bonds with their mothers but with the community as well. 
Table 4. The Return of Si Buncik

\begin{tabular}{|c|c|c|}
\hline $\begin{array}{c}\text { Carito Bancah Buinguik Parents' } \\
\text { Version }\end{array}$ & $\begin{array}{l}\text { CaritoTobek si Ombia } \\
\text { Parents' Version }\end{array}$ & $\begin{array}{c}\text { CaritoAwang Takuluak Parents' } \\
\text { Version }\end{array}$ \\
\hline $\begin{array}{l}\text { Jadi lah baliaknyo ka Mokah. } \\
\text { Amaknyo iko lah bansaik didapati, } \\
\text { rumah godang lah dipaluk aka, kok } \\
\text { lamannyo lah rimbo, kok inyo rang } \\
\text { tuo lah bansaik. Jadi dek lah tadonga } \\
\text { urang pulang dari Mokah }\end{array}$ & $\begin{array}{l}\text { Sudah itu. "Ndeh ndak takona } \\
\text { Amak lai nak, lah lupo jo Amak } \\
\text { tu?" keceknyo. Iko Amak Ang ma, } \\
\text { Amak Peto," kecek into. Kudian } \\
\text { inyo mangamuak-ngamuak. } \\
\text { Ditendangnyolah napan nan baisi } \\
\text { lopek itu. Tu manangih amaknyo. } \\
\text { "Baa ang kok model iko, padohal } \\
\text { dulu ang santun, keceknyo. "Kau } \\
\text { ndak Amak den bagai do, Amak den } \\
\text { rancak den tinggaan dulu. Amakko } \\
\text { iyo lah gaek. Ndak juo inyo nomuah } \\
\text { mangakui do. "Kok ndak nomuah ang } \\
\text { mangakui bialah }\end{array}$ & $\begin{array}{l}\text { Waktu inyo pulang itu ibunyo poi } \\
\text { kadokek inyo. Siap itu ndak picayo } \\
\text { si Buncik bahaso itu ibunyo. Dulu } \\
\text { ibunyo masih rancak, masih mudo, } \\
\text { ndak picayo inyo do itu ibunyo. Ndak } \\
\text { picayo dek dulu ibunyo masih rancak } \\
\text { ndak tuo, tapi kini kok bontuak iko } \\
\text { kini }\end{array}$ \\
\hline $\begin{array}{l}\text { (So he had returned from Mecca. } \\
\text { He found that his mother had fallen } \\
\text { poor, the rumah gadang was covered } \\
\text { in vines, the yard was a jungle, and } \\
\text { theelders poor. So it was heard that he } \\
\text { had returned from Mecca.) }\end{array}$ & $\begin{array}{l}\text { (After that, "Ondeh doesn't remember } \\
\text { Mother any more... you have } \\
\text { forgotten your mother?", she said. } \\
\text { "This is your mother, Emak Peto,"she } \\
\text { said. And then he got angry. } \\
\text { He kicked the napanthat was filled } \\
\text { with lepat (k.o. food). Of course his } \\
\text { mother cried. "Why are you like this } \\
\text { now? Before you were so polite," } \\
\text { she said. "You are not my mother! } \\
\text { My mother was beautiful when I left } \\
\text { her. This woman is old." But he didn't } \\
\text { want to recognize her. "If you don't } \\
\text { want to recognize me, fine."). }\end{array}$ & $\begin{array}{l}\text { (When he was going to go abroad, his } \\
\text { mother was still beautiful, not old. Si } \\
\text { Buncik couldn't believe that she was } \\
\text { his mother, such was her form now.) }\end{array}$ \\
\hline
\end{tabular}

At the time, communal, social, and emotional bonds were still strong, with less of an emphasis on the individual. A daughter would be taught not only by her birth mother, but by all of the women living together in the rumah gadang, who shared the responsibility of shaping the character of the child. Care, education, and motivation could be received from one's grandmother, one's grandmother's sisters, one's mother's sisters, or one's mother's brothers (mamak). They provided not only moral guidance, but also material guidance, to all of the members of the communal family in the same paruik (Anwar, 1997, p. 9).Emotional bonds were shaped because, at the time, the rumah gadang was not only inhabited by one nuclear family, but by several families (Navis, 1984; Kato, 2005; Tanner, 1982).Likewise, the male children would not only receive education and care from their parents, but also their communal families. After reaching the age of ten, male children would no longer sleep in the rumah gadang, but in the surau. In the surau, they would be taught by all of the older men from their family (Azra, 2003, p. 119; Nizal, 2008, p. 75). Presently, life in the rumah gadang and surau has changed. Communal families no longer live together in these places, and thus the nuclear family is responsible for caring and teaching children.

Life in matrilineal families, as it occurred in Minangkabau culture, was closely linked to three topics: 1) heirlooms and land as the source of the matrilineal family's economic wealth, 2) the rumah gadang, where the communal families lived and where family members played their roles, 3 ) the actualization and implementation of traditional teachings. All of these elements were linked to the socio-economic function of 
the matrilineal communal family (Erwin, 2006, p. 123). The rumah gadang of a family was a symbol of that family's existence. Traditional activities and ceremonies were conducted therein. However, today the rumah gadang no longer represent the family, and many have been abandoned by their families. Traditionally, the construction of the rumah gadang was done communally, through mutual assistance, and as such the rumah gadang was also maintained and inhabited together. However, by the late 20 th century, the building of rumah gadang no longer reflected the spirit of Minangkabau tradition. The rumah gadang are now built by people with strong financial capacity and with political interests (Vellinga, 2004).

In the grandparents' version of Carito si Buncik, it is said that, when Si Buncik returned from the rantau in Mecca, the rumah gadang was dilapidated, and as such Si Buncik was unwilling to recognize his mother. He had hoped that the rumah gadang and his mother would be the same as when he had left his homeland, with the rumah gadang standing strong and his mother young and wealthy. However, as reality did not meet his expectations, Si Buncikrefused to recognize his mother. In the parents' and children's version, there is no description of the condition of the rumah gadang; there is only description of Si Buncik's mother as old, poor, and tired. This reflects present-day Minangkabau society's tendency to show little concern for the rumah gadang. The return of Si Buncik is told in table 4.

\section{CONCLUSION}

This research has shown the new reality of the Minangkabau children's carito, which may be considered fairy tales, without conveying serious information. The approach used in this research can be used for other children's stories from throughout the Indonesian archipelago. It has been shown that Minangkabau children's carito reflect the social change that has occurred in Minangkabau society.

This research has shown that two aspects of the carito have changed, namely the selective memories of the storytellers and the matrilineal system. Changes in the memories of the storytellers have been caused primarily by the aging process, although they are also influenced by changes in society. The matrilineal family system of the Minangkabau has also changed in these children's carito, for there has been a shift from the communal family model to the nuclear family model. Changes in the carito can be seen in their characters and these characters' attitudes and behaviors, as told within the stories.

\section{ACKNOWLEDGEMENTS}

This article is part of the author's doctoral dissertation, titled "Carito Anak Minangkabau: Variasi Teks dan Sistem Pewarisannya" (Minangkabau Children's Carito: Variations in their Text and Transmission). This research was made possible through the support of the Ministry of Research, Technology, and Higher Education of Indonesia and Universitas Andalas. As such, the author would like to express her gratitude to her promoter, co-promoter, and all parties who have made this article and dissertation possible.

\section{REFERENCES}

Ahmadi, Abu (2009). Psikologi Umum. Jakarta: Rineka Cipta.

Anwar, Khaidir (1995). Beberapa Aspek Sosio-Kultural Masalah Bahasa. Yogyakarta: Gajah Mada University Press.

Arifin, Zainal (2009). Dualisme dalam Masyarakat Minangkabau (Studi Kasus Perkawinan di Dua Nagari). Dissertation, Postgraduate Program, Faculty of Cultural Sciences, Universitas Gajah Mada.

Azra, Azyumardi (2003). Surau Pendidikan Islam Tradisional dalam Transisi danModernisasi. (trans. Iding Rasyidin). Jakarta: Logos Wacana Ilmu.

Benda-Beckmann, Franz von (1981). Property in Social Continuity: Continuity and Change inthe Maintenance of Property Relationships through Time in Minangkabau, WestSumatra (review by Simon Roberts). Den Haag: Verfassung und Recht in Übersee/ Law and Politics in Africa, Asia and Latin America, 15 (3), 360-364.

Benda-Beckmann, Franz von (2012). Islamic Law in a Plural Context: The Struggle over Inheritance Law in Colonial West Sumatra. Journal of the Economic and Social History of the Orient, 55, 771-793.

Bunanta, Murni (1998). Problematika Penulisan Cerita Rakyat Untuk Anak di Indonesia. Jakarta: Balai Pustaka.

Chatra, Emeraldy (2015). Orang Jemputan Regulasi Seksualitas \& Poligami di Minangkabau. Padang: Faculty of Social and Political Sciences, Universitas Andalas.

Danadjaja, James (1984). Folklor Indonesia: Ilmu Gosip, Dongeng, dan lain-lain. Jakarta: Grafiti.

Danadjaja, James (1998). Pendekatan Folklor dalam Penelitian Bahan-bahan Tradisi Lisan. In Pudentia MPSS (ed.), Metode Kajian Tradisi Lisan. Jakarta: Asosiasi Tradisi Lisan.

Djamaris, Edwar (1991). Tambo Minangkabau. Jakarta: Balai Pustaka

Djamaris, Edwar (2001). Sastra Rakyat Minangkabau: 
Dongeng Jenaka, Dongeng Berisi Nasihat, serta Dongeng Berisi Pendidikan Moral dan Nilai Budaya. Jakarta: Language Center, Department of National Education.

Dobbin, Christine (2008). Gejolak Ekonomi, Kebangkitan Islam, dan Gerakan Padri Minangkabau (17841847). Depok: Komunitas Bambu.

Effendi, Nursyirwan (2016). Pencarian Identitas Orang Minangkabau: Antara Surau dan Tungku Tigo Sejarangan. In Mas'oed Abidin (ed.), Tiga Sepilin Surau Solusi untuk Bangsa. Yogyakarta: Gre Publishing.

Endraswara, Suwardi (2009). Metodologi Penelitian Folklor: Konsep, Teori, dan Aplikasi. Yogyakarta: Media Pressindo.

Erll, Astrid (2011). Memory in Culture (trans. Sara B. Young). London: Palgrave Macmillan.

Erwin (2006). Tanah Komunal Memudarnya Solidaritas Sosial pada Masyarakat Matrilineal Minangkabau. Padang: Andalas University Press

Esten, Mursal (1992). Tradisi dan Modernitas dalam Sandiwara. Jakarta: Intermasa.

Finnegan, Ruth (1992). Oral Traditions and the Verbal Arts: A Guide to Research Practices. London and New York: Routledge.

Gayatri, Satya (2017). Perubahan Nilai-Nilai Kemasyarakatan Pada Carito Anak Minangkabau. Salingka, 14(1), $1-14$.

Graves, Elizabeth E. (2007). Asal-Usul Elite Minangkabau Modern: Respons terhadap Kolonial Belanda Abad $X I X / X X$. Jakarta: Yayasan Obor Indonesia.

Hadler, Jeffrey (2010). Sengketa Tiada Putus: Matriarkat, Reformisme Agama, dan Kolonialisme di Minangkabau. Jakarta: Freedom Institute.

Jones, Andrew (2007). Memory and Material Culture. Cambridge: Cambridge University Press.

Iman, Diah Tyahaya, and A. Mani (2013). Original Research: Motivations For Migration Among Minangkabau Women In Indonesia. Ritsumeikan Journal of Asia Pacific Studies, 32, 114-123.

Jamna, Jamaris (2004). Pendidikan Matrilineal. Padang: Center for Islamic and Minangkabau Studies.

Junus, Umar (1986). Sosiologi Sastera: Persoalan Teori dan Metode. Selangor: Language and Literature Council.

Junus, Umar (1987). Menggali Tradisi dengan Kreatif dan Imajinatif. Selangor: Language and Literature Council.

Junus, Umar (2001). Malin Kundang dan Dunia Kini. Sari $19,69-83$.

Kahn, Joel S. (1980). Minangkabau Social Formations: Indonesian Peasants and the World Economy. Cambridge: Cambridge University Press.

Kato, Tsuyoshi (2005). Adat Minangkabau dan Merantau dalam Perspektif Sejarah (trans. Gusti Asnan and
Akiko Iwata). Jakarta: Balai Pustaka.

Koentjaraningrat (1990). Pengantar Ilmu Antropologi. Jakarta: Rineka Cipta.

Koster, G.L. (1995). Kaca Mata Hitam Pak Mahmud Wahid atau Bagaimanakah Meneliti Puitika Sebuah Sastra Lisan. In Pudentia (ed). Metode Kajian Tradisi Lisan. Jakarta: Asosiasi Tradisi Lisan.

Manan, Imran (1995). Birokrasi Modern dan Otoritas Tradisional di Minangkabau (Nagaridan Desa di Minangkabau). Padang: Yayasan Pengkajian Kebudayaan Minangkabau.

Marnita, Rina (2015). Pergeseran Bahasa dan Identitas Sosial dalam Masyarakat Minangkabau: Studi Kasus Kota Padang. Downloaded from http://staff.unand.ac.id/ rinamarnita/2015/05/13/pergeseran-bahasa-danidentitas- sosial-dalam-masyarakat-minangkabaukota-studi-kasus-di-kota-padang/ on January 14, 2017.

Martono, Nanang (2012). Sosiologi Perubahan Sosial: Perspektif Klasik, Modern, Posmodern, dan Poskolonial. Jakarta: Raja Grafindo Persada.

Miles, Matthew B., andA. Michael Huberman (1992). Analisis Data Kualitatif: Buku Sumber Tentang Metode-Metode Baru (trans. Tjetjep Rohendi Rohidi). Jakarta: Universitas Indonesia.

Mursini (2011). Apresiasi \& Pembelajaran Sastra AnakAnak. Bandung: Citapustaka Media Perintis.

Musfiroh, Tadkiroatun (2008). Memilih, Menyusun, dan Menyajikan Cerita untuk Anak Usia Dini. Yogyakarta: Tiara Wacana.

Naim, Mochtar (1985). Merantau: Pola Migrasi Suku Minangkabau. Yogyakarta: Gadjah Mada University Press.

Navis, A.A. (1984). Alam Terkembang Jadi Guru Adat dan Kebudayaan Minangkabau. Jakarta: Grafiti Pers.

Navis, A.A. (1986). Malin Kundang, Ibunya Durhaka. Kompas, 6.

Nizal, Samsul (2008). Memperbincangkan Dinamika Intelektual dan Pemikiran Hamka tentang Pendidikan Islam. Jakarta. Kencana Prenada Media Group.

Nordelma, Perry (2008). The Hidden Adult: Defining Children's Literature. Maryland: The Johns Hopkins University Press

Nurgiyantoro, Burhan (2004). Sastra Anak: Persoalan Genre. Humaniora, 16(2), 107-122.

Nurgiyantoro, Burhan (2005). Sastra Anak: Pengantar Pemahaman Dunia Anak. Yogyakarta: Gajah Mada University Press.

Ong. Walter J. (2013). Kelisanan dan Keberaksaraan (trans. Rika Iffati). Yogyakarta: Gading Publishing.

Riyadi, Slamet, et al. (1995). Cerita Anak-Anak Dalam Bahasa Jawa. Jakarta: Center for Language Guidance and Development, Department of Education and Culture. 
Ronidin (2011). Malin Kundang, Ibunya Durhaka: Suatu Pendekatan Genetik. Jurnal Lingua Didaktika, 4(2), 114-125.

Rosidi, Ajip (1995). Sastra dan Budaya Kedaerahan dalam Keindonesiaan. Jakarta: Pustaka Jaya.

Rubin, David C. (1995). Memory in Oral Traditions: The Cognitive Psychology of Epics, Ballads, and Counting Out Rhymes. New York: Oxford University Press.

Sairin, Sjafri (2002). Perubahan Sosial Masyarakat Indonesia: Perspektif Antropologi.Yogyakarta: Pustaka Pelajar.

Salim, Agus (2014). Perubahan Sosial: Sketsa Teori dan Refleksi Metodologi Kasus Indonesia. Yogyakarta: Tiara Kencana.

Salim, Ampera, and Zulkifli (2004). Minangkabau dalam Catatan Sejarah yang Tercecer. Padang: Citra Budaya.

Sarumpaet, Riris K. Toha (2010). Pedoman Penelitian Sastra Anak. Jakarta: Yayasan Pustaka Obor Indonesia.

Seokanto, Soerjono (2015). Sosiologi: Suatu Pengantar. Jakarta. Raja Grafindo Persada.

Sikana, Nana (2007). Teras Sastera Melayu Tradisional. Singapore: Karya.

Simatupang, Lono Lastoro (2011). Penelitian Cerita Rakyat. Paper presented at the quality improvement of technical staff activity, Language Center of Yogyakarta, University Hotel, Sleman, 2-3 November 2011.

Stark, Alexander (2013). The Matrilineal System of the Minangkabau and its Persistence Throughout History: A Structural Perspective. Southeast Asia: A Multidisciplinary Journal, 13, 1-13.

Sugihastuti (2013). Tentang Cerita Anak. Yogyakarta: Pustaka Pelajar.

Sukatman (2009). Butir-Butir Tradisi Lisan Indonesia: Pengantar Teori dan Pembelajarannya. Yogyakarta: Laks Bang PRESSindo.

Sunarti, Sastri (2013). Kelisanan dan Keberaksaraan dalam Surat Kabar Terbitan Awal di Minangkabau (18591994-an). Jakarta: Gramedia.

Supartinah (2013). Contribution of Nusantara Children's Classic Literature For Culture-Visioned Primary Education. Paper presented at the International Seminar on Quality and Affordable Education. Downloaded from http://educ.utm.my/wp-content/ uploads/2013/11/48.pdf on March 2, 2014, 358-361.

Suwarsono and Alvin YSo. (2006). Perubahan Sosial dan Pembangunan (revised edition). Jakarta: Pustaka LP3ES.

Suwarna, Budi, and Indira Permanasari (2013). Jejak Para Perantau. Downloaded from http://travel.kompas. com/read/2013/09/09/0746257/Jejak.Para.Perantau on August 24, 2017.

Sweeney, Amin (1998). Surat Naskah Angka Bersuara; Ke Arah Mencari 'Kelisanan'. In Pudentia(ed.), Metodologi Kajian Tradisi Lisan. Jakarta: Asosiasi
Tradisi Lisan.

Sztompka, Piotr (2014). Sosiologi Perubahan Sosial (trans. Alimandan). Jakarta: Prenadamedia.

Tanner, Nancy Makepeace (1982). The Nuclear Family in Minangkabau Matriliny: TheMirror Of Disputes. Bijdragen tot de Taal-, Land- en Volkenkunde, 138(1), 129-151.

Taslim, Noriah (2010). Lisan dan Tulisan. Kuala Lumpur: Language and Literature Council.

Taum, Yoseph Yapi (2011). Studi Sastra Lisan: Sejarah. Teori, Metode, dan Pendekatan Disertai Contoh Penerapannya. Yogyakarta: Lamalera.

Teeuw, A. (1994). Indonesia Antara Kelisanan dan Keberaksaraan. Jakarta: Pustaka Jaya.

Teeuw, A. (2013). Sastra dan Ilmu Sastra: Pengantar Ilmu Sastra. Jakarta: Pustaka Jaya.

Tucker, Elizabeth (2008). Children's Folklore: A Handbook. London: Grenwood Press.

Tulius, Juniator (2013). Family Stories: Oral Tradition, Memories of the Past, and Contemporary Conflicts Over Land in Mentawai, Indonesia. Wacana: Journal of the Humanities of Indonesia, 15(1).

Tumblety, Joan (2013). Memory and History: Understanding Memory as Source and Subject. London and New York: Routledge.

Vansina, Jan (1985). Tradisi Lisan sebagai Sejarah (trans. Astrid Reza et al.).Yogyakarta: Ombak.

Vellinga, Marcel (2004). The Inventiveness of Tradition: Authenticity in Minangkabau Vernacular Architecture. Traditional Dwellings and Settlements, 16(1).

Walgito, Bimo (1980). Pengantar Psikologi Umum. Yogyakarta: Andi.

Yoeti, Oka A. (2017). Diaspora Perantau Minang: Sukses di Rantau, Enggan Pulang Kampung. Bandung: Angkasa.

Yudhiani, Walan (1998). Surau dan Perubahan Sosial Masyarakat Minangkabau (Studi Kasusdi Kenagarian Taram, Kecamatan Harau, Kabupaten 50 Kota. Dissertation Postgraduate Program in Sociology, Universitas Gajah Mada.

Yunus, Yulizar (2015). Minangkabau Social Movement. Padang: Imam Bonjol Press.

Zainuddin, Musyair (2013). Minangkabau dan Adatnya: Adat Bersendi Syarak, Syarak Bersendi Kitabullah. Yogyakarta: Ombak. 